\title{
A metáfora do corpo: um olhar sobre a obra de Emily Martin
}

\author{
A mulher no corpo: uma a nálise \\ cultural da reprodução.
}

MARTIN, Emily.

Rio de Janeiro: Garamond, 2006. 378 p.

A obra da antropóloga americana Emily Martin é uma passagem obrigatória à quelesque se interessam pelo estudo da racionalidade médica e das representações do corpo feminino. Public ado em $1987,{ }^{1}$ e traduzido para o português em 2006 com o título A mulher no corpo, o livro mostra como valores cultura is ma is a mplos se inscrevem nos discursos médicos sobre a reprodução feminina e nas percepções das próprias mulheres acerca de seus corpos.

Diferentemente de muitos estudos na á rea das ciências sociais, que tendem a privilegiara análise de apenas um nível discursivo, seja o científico, seja o leigo, a autora empreende uma pesquisa de fôlego sobre os pressupostos culturais que penetram a um só tempo os disc ursos médic os e de 165 mulheres residentes em Baltimore, Estados Unidos, de diferentes etnias e camadas sócio-econômicas.

Essa análise exige um empenho metodológico no sentido de desnaturalizar verdades muito caras vinculadas às concepções modernas sobre natureza e cultura. Nesse aspecto, a opção pela investigação do imaginário social em tomo do corpo feminino, mediante a decodificação das vozes simultâneas de leigos e especialistas, já toma o trabalho de Martin instigante e inovador.

Investigando os discursos sobre a menopausa, a menstruação e o parto, a a utora conduz o leitor à complexa trama semântica formada pela articulação entre os pressupostos ma is gerais da organização social, a racionalidade biomédica e as percepções e práticas de mulheres comuns sobre seus corpos. A noção de metáfora é o conceito-chave para compreender a comunicação entre essas diferentes dimensões discursivas, a o mesmo tempo que preserva a singularidade e a gramática particular de estruturação de cada uma delas.

O livro é dividido em duas partes, que oferecem uma rica descrição dos saberes médicos e das mulheres entrevistadas, respectivamente. Na primeira, Martin mergulha no discurso médico sobre a reprodução feminina, ma is especificamente na construção científica dos processos da menstruação, da menopausa e do parto, no período de fins do século XIX a meados do XX. A partir de uma convincente argumentação, a a utora demonstra como o modelo médico sobre o funcionamento do corpo feminino está estreitamente relacionado ao modo de orga niza ção ind ustrial c a pita lista.

À luz do que designa como "a metáfora da máquina", a autora descreve a concepção do corpo feminino como uma grande fábrica destinada a produzir bebês saudáveis. Assim, o útero equivaleria a uma máquina de produção desses bebês; a mulher, à operária da fábrica; e o médico, a o supervisor que coordena as atividades do complexo útero-mulher. Nesse modelo, as mulheres estariam a lienadas do produto de seu trabalho e submetidas ao poder do médico-supervisor. Essa mecanização do corpo feminino é ilustrada pelo processo de substituição da mão das parteiras por instrumentos como o fórceps e o bisturi.

A metáfora do corpo como máquina também se explicita a partir da descrição da menstruação e da menopausa, ambas resultantes de uma espécie de falha no sistema produtivo. 0 sangue menstrual sinalizaria um fracasso naquilo que deveria ser o produto do 
processo reprodutivo. Já a menopausa seria representada como uma ruptura no funcionamento hierárquico do sistema de sinalização entre cérebro, hormônios e ovários; assim, ela resultaria da impossibilidade de os ovários cumprirem a ordem advinda do 'centro hipotalâmico' (cérebro), o que produziria uma desordem no sistema reprodutivo feminino.

Sendo o corpo da mulher representado como uma grande fábrica voltada para a produção de bebês saudáveis, tudo a quilo que se desvia de tal objetivo é desqua lific ado e visto como patológico, desperdício, inutilidade, desordem, excesso, falha. Martin faz um interessante questionamento à natureza teleológic a desse modelo, que pauta o seu valor e a sua finalidade na reprodução.

Uma das qualidades da primeira parte do livro é desvelar - a partir de fontes médicas - as suposições cultura is implíc itas em um discurso altamente natura liza do e natura lizante. Ou seja, fundamentar aquilo que torna a ciência um sistema cultural e mostrar, assim, que as idéias subjac entes a um corpo reprodutor feminino são fomentadas por uma cultura. Desse modo, a a utora descortina, com engenhosidade, o a specto cultural e o seu papel na construção científica de uma natureza feminina.

Na segunda parte do livro, Martin se a tém aos depoimentos de mulheres, numa tentativa de identificar os focos de incorporação do modelo médico, mas, sobretudo, de resistência e de liberação a o mesmo modelo. Nessa parte, fic am evidentes as implic ações de sua abordagem feminista da ciência - posição assumida no prefác io da edição de 1992 -, o que contribui para uma atitude analítica diferencial em relação às falas das mulheres quando comparada à análise do discurso médico. A autora investiga os depoimentos de mulheres sobre temas como a 'síndrome pré-menstrual', a menstruação, o parto e a menopausa. Porém, de modo distinto da análiseu e efetuada na primeira parte, busca ativamente os signos de resistência à opressão contra a mulher.

O sentimento de raiva, por exemplo, um dos sintomas da 'síndrome pré-menstrual', é concebido como uma manifestação da indignação das mulheres pela situação de opressão vivenciada por elas. Para Martin, o problema maior, nesse caso, residiria na a tribuição de uma causalidade física pelas mulheres ao que seria resultante de um funcionamento social mais geral. A conscientização da real signific ação dessa raiva (a opressão vivida pelas mulheres) é defendida pela pesquisadora como um caminho para a liberação, evidenciando, em seus argumentos, a influência do pensamento marxista.

Martin segue a mesma linha argumentativa a o a firmarque existiria uma 'experiência corpora comum' às mulheres. Paralelamente à defesa da conscientização dos meca nismos soc ia is que transformam o corpo da mulher numa fábrica de produção, ela postula que a experiência corporal feminina pode ser usada como um veículo de resistência e libertação da subordinação da mulher.

Nas narrativas das informantes, a autora vislumbra algumas tentativas de reintegração e apropriação das forças produtivas do próprio corpo, a tra vés da vivência íntima das experiências corpora is e da destituição - mesmo que não integral - da intervenção do médicosupenisor no processo reprodutivo feminino. No caso do parto, por exemplo, ela identifica as estratégias das gestantes de adiar a chegada a o hospital e vivenciara o máximo as contrações do parto em casa. Isso seria uma forma de resistência a o modelo médico, que expropriaria a operária-mulher do produto de sua força de trabalho.

À medida que os capítulos avançam, intensifica-se o engajamento de Martin em prol de uma autonomização e reintegração das mulheres a partir das suas experiências corpora is. No último capítulo, essa posição é levada ao extremo, a tra vés da argumentação de que ta is experiências femininas, diferentemente das masculinas, favoreceriam uma visão de mundo global - que integraria dicotomias ta is como público e privado, trabalho manual e mental, entre outras.

O trabalho de Martin tem o mérito de evidenciar o modo como a cultura afeta as construções médicas e de mulheres comuns. Porém, a alusão a uma experiência comum a todas as mulheres remete, de modo paradoxal, a uma espécie de essência feminina calcada no corpo. A a firmação de uma experiência feminina comum parece associada ao fato de a pesquisadora não problematizar os pressupostos cultura is que qua lific a m como 'femininas' determinadas experiências corpora is. Nesse sentido, o feminino acaba se vinculando muito rapidamente a um corpo específico e se toma uma espécie de substantivo, que, como tal, está ind issocia velmente associado a esse corpo.

Essa questão conduz à reflexão sobre a concepção de gênero implícita na obra de Martin. Quanto a esse aspecto, é interessante notarque a autora fala na realidade de 'corpos 
de mulheres', o que não parece equivaler, em última instância, à idéia de 'corpos femininos'. Assim, chama a atenção o fato de que a autora dia loga ma is com indivíduos empíricos e menos com categorias analíticas e abstratas que classificam e ordenam os indivíduos em um espaço social. Tal ponto de vista parece facilitar a a proximação das mulheres a um corpo comum, uma vez que Martin fala de seres empíricos, cuja classific ação (em um corpo feminino que se opõe a um outro, masculino) fol previamente estabelecida.

Martin acaba positivando a experiência física do corpo, que serve, dessa forma, como base comum às mulheres para a liberação da o pressão social a que elas estariam submetidas. Em certos momentos, a defesa da resistência e liberação da dominação masculina acaba se antecipando e conduzindo a própria interp retação dos dados, rea firmando-se, a ssim, a premissa da opressã o feminina. ${ }^{2}$

Mesmo considerando os risc os inerentes a essa argumentação, a sua análise não deixa de ser provocativa. Conforme Rohden salienta na apresentação do livro de Martin, ao mesmo tempo que a antropóloga americana trabalha nos marcos de um construcionismo social, não deixa de conceder um valor particular à experiência do corpo. Poucos cientistas socia is tiveram a audácia de a misca resse tipo de leitura, o que confere à obra um sentido de novidade, que permanece até hoje, apesar de passados vinte anos desde a sua publicação.

\section{Notas}

${ }^{1}$ MARTIN, 2001.

${ }^{2}$ Fabíola ROHDEN, 1998

\section{Referências bibliográficas}

MARTIN, Emily. The Woman in the Body: A Cultural Analysis of Reproduction. Boston: Beacon Press, 2001 [1987].

ROHDEN, Fabíola. "O corpo fazendo a diferença". Mana, v. 4, n. 2, p. 127-141, 1998.

Femanda de Carvalho Vecchi Alzuguir Instituto de Medicina Social/UERJ 